DOI: https://doi.org/10.30525/978-9934-26-108-4-13

Anna Kornyliuk

Candidate of Economic Sciences, Associate Professor, Associate Professor at Corporate Finance and Controlling Department Kyiv National Economic University named after Vadym Hetman

Alla Ivashchenko

Doctor of Economic Sciences, Associate Professor, Associate Professor at Corporate Finance and Controlling Department Kyiv National Economic University named after Vadym Hetman

\title{
REGIONAL CLUSTER ANALYSIS AS APPROACH FOR SME DEVELOPMENT MODELS
}

\section{Summary}

The study analyzes the SME development regional trends in terms of key indicators. Using K-means clustering techniques, 4 groups were identified. Data show that the largest gap between the most and least developed clusters is observed in terms of spending on business innovation expenditures per capita, at the same time the average wage is the most consistent indicator. The obtained results allow to form recommendations for the intensification of innovation and investment development of small and medium-sized businesses, taking into account regional specifics. The set of recommendations was divided into financial and non-financial support measures. It is proposed to use mainly direct support aimed at stimulating individual projects for more developed regions, while for less developed regions it is advisable to use indirect tools. Non-financial support measures should be aimed primarily at eliminating institutional and systemic failures in business.

\section{Introduction}

Small and medium-sized enterprises play an important role in shaping the socio-economic environment of any region: the sector is the employer of up to $75 \%$ of workforce, and the SME sector is forming $90 \%$ of all registered companies. At the same time, the unfavorable institutional environment, lack of knowledge and difficult access to financial resources significantly slow down the innovative development of SMEs.

Under the circumstances, effective state and regional support measures for SMEs can be a powerful source of intensification of innovation processes in small and medium-sized businesses. At the same time, the grouping of Ukraine's regions into macro-regions by geographical criterion in order to form a regional SME development policy carries certain risks, as neighboring regions often differ in key socio-economic and financial indicators. At the same time, some regions that represent different parts of the country may 
have similar economic parameters, and therefore their support programs will contain a common list of measures.

The above determined the purpose of the study, which was to group regions by the main features of economic and innovative development of SMEs using cluster analysis methods and further development of recommendations for SME development models.

\section{Part 1. Cluster analysis of Ukrainian regions according to key indicators of SME development}

Data and methodology.

Data from the State Statistics Committee for 2019 for 24 oblasts were used for cluster analysis. All data were standardized according to formula (1) to reduce the dimensionality of the data:

$$
x_{i j}^{H}=\frac{x_{i j}-\overline{x_{j}}}{\sigma_{i}}
$$

The regions were grouped using the K-means method, which divides a sample of $\mathrm{D}$ data from $\mathrm{n}$ objects into $\mathrm{K}$ clusters, optimizing the objective function (each object belongs to the cluster with the closest average value).

In order to determine the degree of closeness of the studied data at each stage, the Euclidean metric was used. Minimization of the sum of the squares is calculated using the formula (2), where ck is the centroid of the cluster Ck:

$$
\operatorname{SSE}(C)=\sum_{k=1}^{K} \sum_{x_{i e c k}}\left\|x_{i}-c_{k}\right\|^{2}
$$

The clustering algorithm included the following steps:

1. Determination of the number of clusters

2. Selection of the centroids for each cluster

3. Grouping the observations around the nearest centroid

4. Choosing the new centroids

The final number of clusters was chosen by the «elbow method», according to which the number of clusters is selected if the addition of another cluster does not give a significantly better modeling result (Figure 1). In the case of this data set, adding a fifth cluster does not significantly reduce the sum of the squares of the distances of the objects within the clusters. Therefore, it is advisable to form 4 clusters, and the ratio of the sum of the squares of the distances between the clusters to the total sum of the squares of the distances between the objects is $77 \%$, which indicates a sufficient density of the resulting clusters.

The initial sample of indicators tested to identify groups of similar regions included 8 indicators, of which 5 were used in the final model:

1. Innovation expenditures per capita is an indicator that reflects the ability of small and medium-sized businesses in the region to finance innovative transformations.

2. Gross regional product per capita indicates the total cost of goods, services that have been produced in the region and is a key indicator of economic capacity of the region. 


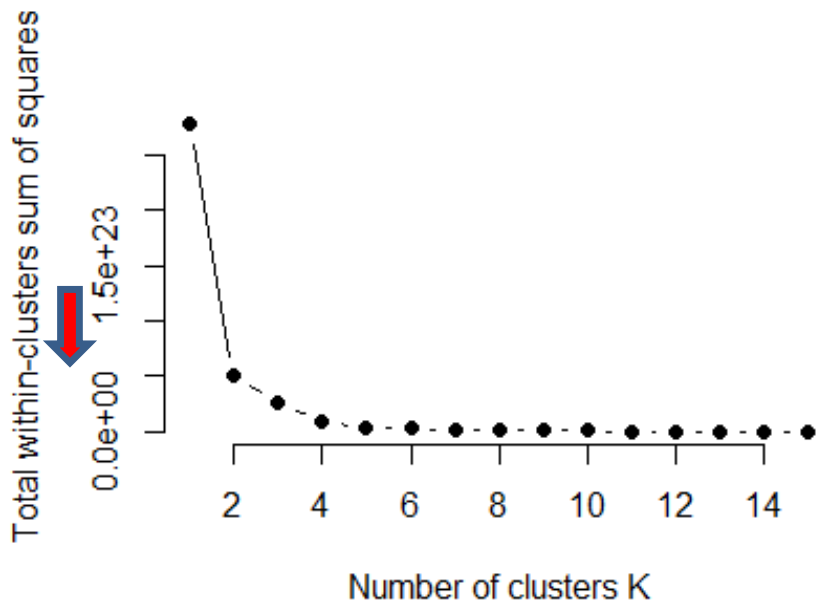

Figure 1. Application of the «elbow» method in selectiong the optimal number of clusters

3. The average wage is an indicator of the attractiveness of the region from the point of view of the workforce.

4. Exports per capita is an indicator that indicates the activity of the region in foreign markets.

5. Sales of SME sector is an indicator of small and medium business development.

Three out of five indicators are calculated per capita, which allows to eliminate differences in the size of regions.

As mentioned above, the results of the analysis were 4 clusters.

The median values of the used indicators of regional development by cluster are given in Table 1.

As can be seen from the Table 1, the most developed regions are included in cluster 2, which has significantly higher median indicators of regional development compared to other clusters. The largest gap is observed in indicators of innovation expenditures per capita and exports per capita. At the same time, in terms of average wages and GRP per capita, the gap is not so significant, although it is also present.

Table 1

Median values of indicators by clusters

\begin{tabular}{|c|c|c|c|c|c|}
\hline Cluster & $\begin{array}{c}\text { Innovation } \\
\text { expenditures } \\
\text { per capita } \\
\text { (UAH) }\end{array}$ & $\begin{array}{c}\text { GRP per } \\
\text { capita } \\
\text { (UAH) }\end{array}$ & $\begin{array}{c}\text { Average } \\
\text { wage } \\
\text { (UAH) }\end{array}$ & $\begin{array}{c}\text { Export } \\
\text { volume } \\
\text { per capita } \\
\text { (UAH) }\end{array}$ & $\begin{array}{c}\text { Sales } \\
\text { (UAH } \\
\text { billion) }\end{array}$ \\
\hline 1 & 165.41 & 84558.74 & 9911.00 & 31655.00 & 228.33 \\
\hline 2 & 907.23 & 93410.11 & 10480.00 & 51772.98 & 318.12 \\
\hline 3 & 28.73 & 72064.09 & 8667.50 & 21091.54 & 89.47 \\
\hline 4 & 28.01 & 55004.83 & 8275.00 & 7409.42 & 63.49 \\
\hline
\end{tabular}

Source: State Statistics Service, authors estimations 

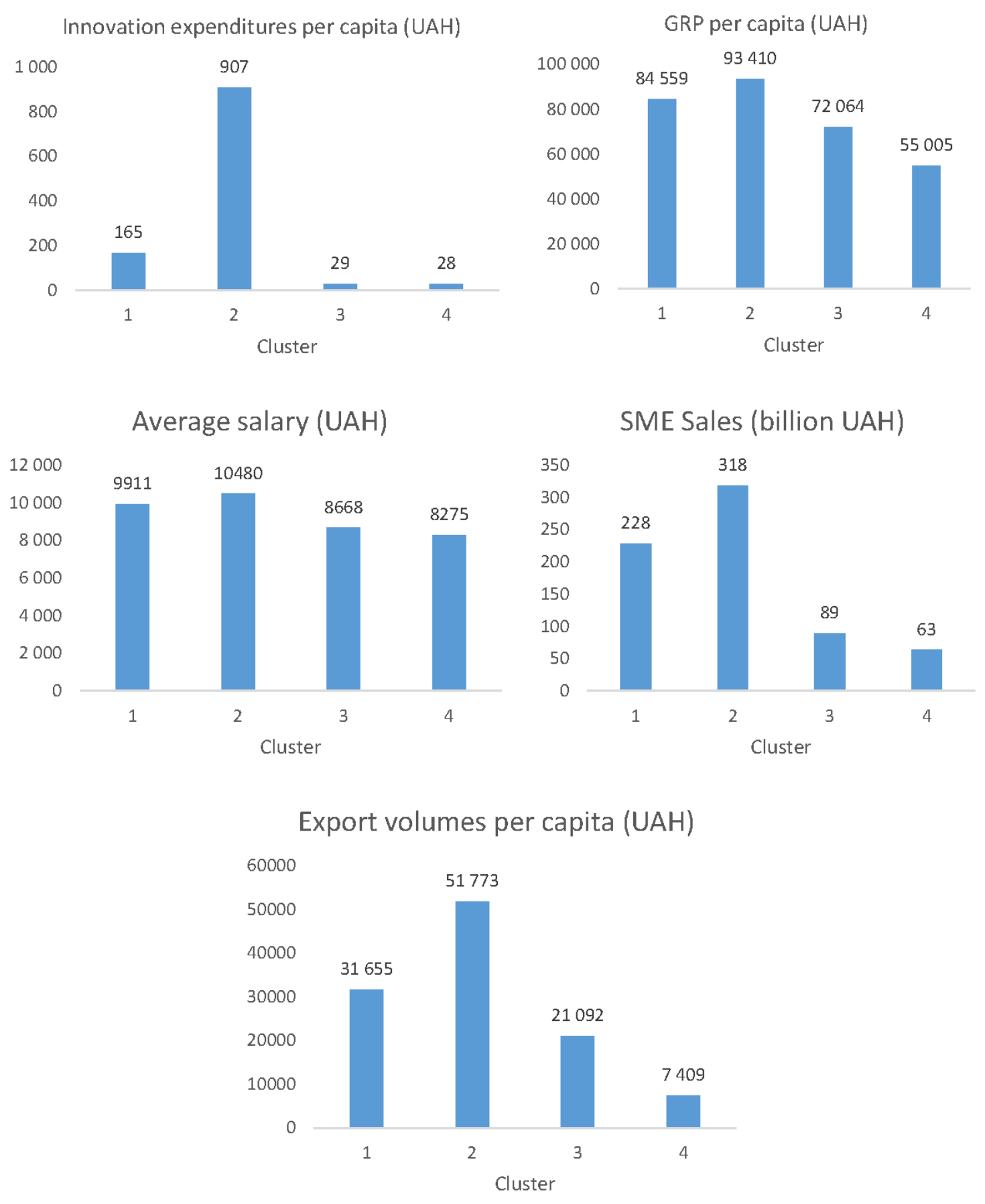

Figure 2. Indicators of SME development by cluster (median values)

Source: State Statistics Service, authors estimations

Cluster 1 is characterized by lower rates compared to the leading regions, but has a much more developed compared to clusters 3 and 4 .

Regions with the worst values of the studied indicators were included in the 4th cluster. The only indicator, for which there is no significant lag - this is the average wage, while the innovation expenditures per capita is 32 times lower compared to cluster 1 , exports -7 times, SME revenue -5 times. 


\section{Part 2. Characteristics of obtained clusters}

The first cluster includes 6 oblasts: Donetsk, Kyiv, Lviv, Mykolaiv, Odesa, and Poltava oblasts.

As noted above, the cluster is characterized by moderate levels of regional development indicators.

Table 2

Regional development indicators for cluster 1

\begin{tabular}{|l|c|c|c|c|c|}
\hline Region & $\begin{array}{c}\text { Innovation } \\
\text { expenditures } \\
\text { per capita } \\
\text { (UAH) }\end{array}$ & $\begin{array}{c}\text { GRP per } \\
\text { capita } \\
\text { (UAH) }\end{array}$ & $\begin{array}{c}\text { Average } \\
\text { wage (UAH) }\end{array}$ & $\begin{array}{c}\text { Export } \\
\text { volume } \\
\text { per capita } \\
\text { (UAH) }\end{array}$ & $\begin{array}{c}\text { Sales } \\
\text { (UAH } \\
\text { billion) }\end{array}$ \\
\hline Donetsk & 7,86 & 49576,29 & 11716,00 & 31915,16 & 134,94 \\
\hline Kyiv & 236,16 & 123670,15 & 11003,00 & 31394,85 & 328,33 \\
\hline Lviv & 186,30 & 85826,41 & 9271,00 & 25116,64 & 298,44 \\
\hline Mykolaiv & 210,36 & 82203,02 & 9976,00 & 54541,93 & 105,01 \\
\hline Odesa & 144,53 & 83291,06 & 9246,00 & 16660,38 & 281,76 \\
\hline Poltava & 32,18 & 135208,21 & 9846,00 & 43235,41 & 174,90 \\
\hline
\end{tabular}

Source: State Statistics Service, authors estimations

The data show that the cluster is not homogeneous in terms of innovation expenditures: Poltava and Donetsk oblasts finance innovation development several times less than in other oblasts in the cluster. Kyiv and Mykolaiv oblasts are leading. Studies show that the latest local microbusiness demonstrates a willingness to intensify innovation, including the production of new products [1].

Indicator of gross regional product is more homogeneous, except for Donetsk oblast. The leaders in terms of GRP per capita are Kyiv and Poltava regions. The remaining oblasts in the studied cluster have GRP per capita at the level of approximately 80,000 UAH.

The average salary is the most consistent indicator among all and ranged 911 thousand UAH. The highest salaries were recorded in Donetsk and Kyiv oblasts - 11,700 UAH and 11,003 UAH, respectively. For the rest of the regions it was in the range of 9200-9800 UAH.

Export volumes per capita ranged from 16 to 54 thousand UAH. The highest volumes were in Mykolayiv and Poltava oblasts (54.5 thousand UAH and 43.2 thousand $\mathrm{UAH}$, respectively), and the lowest - in Odesa (16.7 thousand UAH).

Kyiv oblast leads in terms of SME revenue - 328 billion UAH, the lowest volumes are recorded in Mykolayiv and Donetsk oblasts (135 billion UAH and 105 billion UAH, respectively).

The second cluster includes 3 oblasts: Dnipropetrovsk, Zaporizhzhia, Kharkiv. 
These are the leading oblasts in the set of studied indicators of regional development.

Table 3

Regional development indicators for cluster 2

\begin{tabular}{|l|c|c|c|c|c|}
\hline Region & $\begin{array}{c}\text { Innovation } \\
\text { expenditures } \\
\text { per capita } \\
\text { (UAH) }\end{array}$ & $\begin{array}{c}\text { GRP per } \\
\text { capita } \\
\text { (UAH) }\end{array}$ & $\begin{array}{c}\text { Average } \\
\text { wage } \\
\text { (UAH) }\end{array}$ & $\begin{array}{c}\text { Export } \\
\text { volume } \\
\text { per capita } \\
\text { (UAH) }\end{array}$ & $\begin{array}{c}\text { Sales } \\
\text { (UAH } \\
\text { billion) }\end{array}$ \\
\hline Dnipro & 724.5 & 122507.5 & 10751.0 & 70682.5 & 456.9 \\
\hline Zaporizhzhia & 907.2 & 91539.2 & 10480.0 & 51773.0 & 141.0 \\
\hline Kharkiv & 1080.3 & 93410.1 & 9081.0 & 15210.6 & 318.1 \\
\hline
\end{tabular}

Source: State Statistics Service, authors estimations

First of all, the oblasts are characterized by extremely high rates of innovation expenditures per capita, due to the fact that in the regions there are enterprises producing innovative products, powerful research centers, as well as these areas are characterized by the development of IT technologies and IT community. All this creates a favorable ecosystem for the development of small and medium-sized businesses, which can provide related services to large knowledge-intensive companies and institutions.

The gap in GRP values per capita is not significant (unlike the areas in the first cluster). Dnipropetrovsk oblast leads in this indicator - 122 thousand UAH, Zaporizhzhia and Kharkiv oblast have slightly lower indicators 91.5 thousand UAH and 93.4 thousand UAH, respectively.

It should be noted that only two oblasts have higher GRP per capita Poltava and Kyiv, but they have been placed to the first cluster due to the worse results of other indicators.

The average wage for the cluster ranges from 9 to 10.7 thousand UAH. The leader in terms of exports per capita is Dnipropetrovsk oblast - 70.6 thousand $\mathrm{UAH}$, which is the largest indicator among all oblasts. Kharkiv oblast is much less export-oriented - only 15.2 thousand UAH.

In terms of SME revenue, Dnipro oblast is also in the lead in terms of this indicator - 456.9 billion UAH, Kharkiv oblast is in the second place 318 billion UAH, and Zaporizhzhia oblast is more than twice as low - only UAH 141 billion.

The third cluster is the most numerous and includes 10 regions with regional development indicators close to the national average: Vinnytsia, Volyn, Zhytomyr, Zakarpattia, Ivano-Frankivsk, Kirovohrad, Sumy, Khmelnytskyi, Cherkasy, Chernihiv.

The regions geographically represent all parts of Ukraine, except the East. 
Table 4

Regional development indicators for cluster 3

\begin{tabular}{|l|c|c|c|c|c|}
\hline \multicolumn{1}{|c|}{ Region } & $\begin{array}{c}\text { Innovation } \\
\text { expenditure } \\
\text { s per capita } \\
\text { (UAH) }\end{array}$ & $\begin{array}{c}\text { GRP per } \\
\text { capita } \\
\text { (UAH) }\end{array}$ & $\begin{array}{c}\text { Average } \\
\text { wage } \\
\text { (UAH) }\end{array}$ & $\begin{array}{c}\text { Export } \\
\text { volume } \\
\text { per capita } \\
\text { (UAH) }\end{array}$ & $\begin{array}{c}\text { Sales } \\
\text { (UAH } \\
\text { billion) }\end{array}$ \\
\hline Vinnytsia & 25.62 & 83555.65 & 9299.00 & 26830.94 & 144.15 \\
\hline Volyn & 9.61 & 73410.20 & 8663.00 & 19190.92 & 148.46 \\
\hline Zhytomyr & 21.73 & 70202.50 & 8528.00 & 16866.65 & 87.76 \\
\hline Zakarpattia & 62.04 & 48971.51 & 9202.00 & 33904.24 & 51.83 \\
\hline Ivano-Frankivsk & 30.78 & 63381.06 & 8817.00 & 18989.11 & 76.33 \\
\hline Kirovohrad & 26.69 & 78349.13 & 8360.00 & 21599.23 & 97.50 \\
\hline Sumy & 87.26 & 70717.98 & 8579.00 & 23470.99 & 88.98 \\
\hline Khmelnytskyi & 15.28 & 66081.41 & 8672.00 & 14569.25 & 88.99 \\
\hline Cherkasy & 43.49 & 86578.04 & 8838.00 & 20583.86 & 147.57 \\
\hline Chernihiv & 46.77 & 78790.64 & 8206.00 & 23241.65 & 89.96 \\
\hline
\end{tabular}

Source: State Statistics Service, authors estimations

In terms of innovation expenditures per capita Sumy oblast leads 87.26 UAH, innovation expenditures per capita in Zakarpattia region are 62.04 UAH. Cherkasy and Chernihiv regions have slightly lower indicators at the level of 43-47 UAH. Outsiders in the cluster according to this indicator are Khmelnytsky and Volyn regions - 15 and 9.6 UAH, respectively.

GRP per capita shows less variability compared to the innovation expenditures. Cherkasy and Vinnytsia oblasts produced the most per capita 86,578 UAH and 83,556 UAH, respectively. While the lowest level of GRP per capita was demonstrated by the Zakarpattia region - 48,971 UAH.

As for the previous clusters, the level of the average wage is the least volatile with a maximum value of 9,299 $\mathrm{UAH}$ in Vinnytsia oblast and a minimum value of 8,206 UAH in Zakarpattia oblast.

The most export-oriented region in the cluster is Zakarpattia oblast 33,904 UAH per capita, the smallest volume of exports of goods, works and services was recorded in Khmelnytsky oblast - only 14,569 UAH per capita. Volyn, Cherkasy and Vinnytsia oblasts are the leaders in terms of revenues

The fourth cluster includes the regions with the lowest regional development indicators: Luhansk, Rivne, Ternopil, Kherson, Chernivtsi.

Geographically, the regions are located in the east, west, north and south of Ukraine.

With the exception of Chernivtsi oblast, others have low values of innovation expenditures per capita - a median value of $28 \mathrm{UAH}$, which is less than for the regions of the 3rd cluster. 
Table 5

Regional development indicators for cluster 4

\begin{tabular}{|l|c|c|c|c|c|}
\hline Region & $\begin{array}{c}\text { Innovation } \\
\text { expenditure } \\
\text { s per capita } \\
\text { (UAH) }\end{array}$ & $\begin{array}{c}\text { GRP per } \\
\text { capita } \\
\text { (UAH) }\end{array}$ & $\begin{array}{c}\text { Average } \\
\text { wage } \\
\text { (UAH) }\end{array}$ & $\begin{array}{c}\text { Export } \\
\text { volume per } \\
\text { capita } \\
\text { (UAH) }\end{array}$ & $\begin{array}{c}\text { Sales } \\
\text { (UAH } \\
\text { billion) }\end{array}$ \\
\hline Luhansk & 18.4 & 18838.1 & 8731.0 & 2036.3 & 32.2 \\
\hline Rivne & 15.3 & 58383.8 & 8967.0 & 10870.1 & 63.5 \\
\hline Ternopil & 28.0 & 55004.8 & 8275.0 & 11911.6 & 64.0 \\
\hline Kherson & 70.0 & 60072.0 & 8187.0 & 7409.4 & 64.1 \\
\hline Chernivtsi & 117.5 & 46293.2 & 8066.0 & 6772.0 & 34.6 \\
\hline
\end{tabular}

Source: State Statistics Service, authors estimations

The GRP indicator per capita for the studied regions is in the range from 46 to 60 thousand UAH, except for Luhansk region, for which the value of the indicator is only 18.8 thousand UAH.

The average salary in the cluster does not exceed 9.000 UAH, with a maximum value of 8,900 thousand $\mathrm{UAH}$ in Rivne region and a minimum value of $8.000 \mathrm{UAH}$ in Chernivtsi region.

In addition, the cluster regions are not export-oriented - the median value of exports per capita is only 7.4 thousand UAH (for comparison in the 3rd cluster -21 thousand UAH).

SME revenue among the cluster oblasts is not homogeneous: for Ternopil, Kherson and Rivne oblasts it is about 60 billion UAH, while for Chernivtsi and Luhansk oblasts it is almost half less.

Thus, the study serves as a basis for further recommendations for intensifying the innovative development of small and medium-sized businesses at the local level.

\section{Part 3. Recommendations for the financial support of SMEs development based on a cluster approach}

Government intervention in SME innovation development is justified when private investment in innovation is not able to provide the optimal social effect: private sector investment is too small or investment does not meet the strategic development goals of the country as a whole or individual regions.

At the same time, OECD researchers note that economic and innovative development of regions and overcoming key imbalances should be based on a combination of state and local policies (place-based policies) [2]. Successful local development policies achieve two goals at once: first, they contribute to the actual economic development of the region, and second, they better reflect the economic and cultural characteristics of the region.

An important task of both central and local governments is not only the direct impact on the development of SMART-specializations in the regions 
through the adoption of appropriate legislation, but also the identification and elimination the main barriers for SMEs innovative development.

The main barriers include: insufficient level of entrepreneurial culture in society, low competition or monopoly in some industries, institutional barriers (over-regulation, frequent changes in tax legislation, unsatisfactory level of investor protection, etc.).

Among the key reasons for state intervention in the innovative development of SMEs are: disparities in access to financial capital, access to skilled labor; forming a common investment and innovation system (including the infrastructure of the relevant sectors) [3, p. 62].

For further analysis, we propose to divide the methods of stimulating the innovative development of SMEs at the regional level into the following areas:

1) measures for financial support of SMEs through budgetary, fiscal and monetary policies;

2) measures to remove barriers through the development of an effective stimulating ecosystem to ensure the innovative development of SMEs.

The study conducted in the previous section allowed to identify 4 clusters of regions according to the level of economic and innovative development of SME. Conventionally, these clusters can be divided into two main groups: the first and second clusters include areas with the highest level of key indicators of regional development. In this case, the areas in cluster 1 have a mixed industrial and agricultural profile with a predominance of processing industry, and for Kyiv, Mykolaiv, and Poltava, agriculture also forms a significant share of GRP. In addition, an important component of the economy of Lviv region is the information and telecommunications industries.

For the second cluster the leading industry is the processing industry, in addition, for the Kharkiv oblast - telecommunications, and for the Dnipropetrovsk oblast - the mining industry.

Financial support recommentations for clusters 1 and 2

By direction, financial support includes direct, indirect (fiscal) and mixed types. In our opinion, for regions with a higher level of development, it is advisable to provide direct financial support: funding for R\&D activities of research institutions, universities, funding of innovative firms with mixed ownership, government loans at reduced rates, subsidies, direct government procurement of innovative products.

The experience of countries with developed innovation systems and high innovations expenditures costs (the USA, France, Great Britain) shows the advantage of using direct methods of financial support of certain priority areas [4, p. 15].

One of the features of direct methods of financing investment and innovation development of enterprises is their targeted nature and focus on achieving a specific goal, in contrast to fiscal methods. 
Studies have shown that targeted tax benefits, such as tax credits and rebates, are highly effective compared to broader initiatives: tax holidays and lower corporate tax rates. These findings are confirmed by studies conducted by P. Hanel and A. Altuzarra on the example of Spanish and Canadian companies [5].

According to the subjects of influence, the state financial support provides stimulation of certain industries or horizontal stimulation (elimination of obstacles of functioning for all sectors of economy). For clusters 1 and 2, it is proposed to use the stimulation of certain segments of the economy, which will contribute to the effective implementation of SMART-specialization in these areas.

According to the object of stimulation, financial support should be directed to: obtaining new knowledge (subsidizing university research projects, reducing taxes on scientists and researchers, tax incentives for research and development by enterprises); stimulating the growth of fixed assets (accelerated depreciation, tax benefits and loans); accumulation of human capital (benefits in the taxation of income of researchers, benefits for staff training and management)

Financial support recommentations for clusters 2 and 3

Given that the third and fourth clusters include areas with relatively lower levels of the studied indicators, for the development of SMEs in these regions it is advisable to apply indirect financial incentives, namely fiscal support measures aimed at all SMEs in the region.

Fiscal incentives allow to reduce tax payments as a reward for innovation. Their advantage is the freedom of choice of entrepreneurs in terms of spending within the budget of investment in innovation.

The main disadvantage of such initiatives is the inability of the authorities to fully control the budgets and expenditures of enterprises on investment in innovation. However, this shortcoming is offset by setting limits above which companies cannot receive tax benefits.

As for direct financing measures, they should be aimed primarily at the development of the innovation ecosystem, which will stimulate the development of the entire SME sector and equalize regional disparities.

According to the subjects of influence, the state financial support provides stimulation of separate segments (separate kinds of activity, branches, etc.) or horizontal stimulation (elimination of obstacles of functioning of all links of innovation system). In contrast to the developed areas, for the regions of clusters 3 and 4 it is proposed to use horizontal incentives, which are aimed at removing obstacles to the functioning of all parts of the innovation ecosystem.

According to the object of stimulation, financial support in the studied clusters along with the above areas (gaining new knowledge to stimulate the growth of fixed assets, accumulation of human capital), it is also advisable to stimulate the development of innovation system infrastructure (measures to overcome information asymmetry, etc.). 


\section{Part 4. Recommendations for the non-financial support of SMEs development based on a cluster approach}

In addition to the actual financial support, it is important to form the appropriate infrastructure and climate for business development.

In general, there are three main non-financial areas of SME development in terms of SMART-specialization: 1) regulatory requirements for starting a business; 2) entrepreneurial culture; 3 ) attractiveness of the region and quality of infrastructure [6].

Researchers suggest considering the directions of the SMEs development support through the prism of the market failures concept.

In the process of investing in innovation, the company operates in the commodity market, labor market and the financial market (in order to obtain sufficient resources for the investment project). A significant number of counterparties in such markets increases uncertainty and risks of investment and innovation development of enterprises.

For the first time the term «market failure» was used by a professor at Harvard School F. Bahor in «The Anatomy of Market Failure» [7]. The main market failures are:

- imperfect competition in the markets - weak antitrust policy reduces incentives to innovate;

- external effects or externalities that increase the marginal costs of producers and lead to a loss of expected profits. According to F. Bator, there are three types of such externalities: property, technical and public goods.

- information asymmetry. Not all market participants are well informed, and the information itself is unevenly distributed among potential investors, which leads to a reduction in innovation.

It should be emphasized that the success of supporting measures is determined by not only the type of support provided, but also the way it is implemented (not what kind of support is provided, but how it is provided), which shifts the emphasis on innovative development of enterprises. This thesis confirms the importance of studying and elaborating the concepts of market and system failures as a kind of guide to support innovative development.

The framework should include:

- providing preconditions for innovation (development of education (knowledge economy); infrastructure, access to capital markets);

- development of competition through the enhancing antitrust law, product quality requirements, ensuring consumer rights, etc.;

- reduction of business risks and increase of returns (including due to reduction of information asymmetry) and simplification of the taxation system - elimination of obstacles to investment and innovation activities [8].

In the context of sustainable regional development, digitalization is seen a key factor for the transformation of all sectors of the economy, government and society, based on the large-scale implementation of existing digital technologies, as well as those still in development [9, p. 2]. 
The calculations show a significant correlation between indicators of the availability of technological infrastructure, the adoption of new technologies and the ease of doing business [10, p. 14].

We believe that the negative impact on the development of SMEs is not only the imperfection of the market but also the lack of a favorable business environment. Representatives of the concept of systemic failures (R. Gustafsson, E. Autio, A. van Krusen and H. Hollanders) [11; 12] draw attention to structural, regulatory and institutional shortcomings and gaps that lead to a decline in the optimal level of investment in innovation.

Professors R. Gustafsson and E. Autio of the University of Helsinki, studying innovation systems, identified four types of possible failures: failures in the evolutionary dynamics of innovation systems; lack of connections between the participants of the innovation system; barriers to innovation (lock-in); lack of infrastructural support of the innovation process. Later, A. van Krusen and H. Hollanders combined these types of failures under a single name, «systemic failures».

Systemic failures are structural, institutional and regulatory shortcomings that lead to suboptimal levels of investment in innovation.

K. Smith believes that the inefficient functioning of the innovation system is due to the inability of firms to get rid of the negative externalities, which he called a «trap of isolation» [13, p. 26]. Firms lose the ability to respond quickly to technological change due to dependence on existing systems.

According to the founder of the theory of national innovation systems B. Lundwal, with increasing change, inertia increases, which creates barriers to adaptation to new technologies. Firms are able to adapt to change through the formation of a new technological structure and technological regimes. In case of impossibility, firms are not able to form a new structure of interaction in the innovation system. Failures in the functional elements of the innovation system hinder innovation and therefore require government intervention.

Government policy aimed at combating systemic failures should include areas used to overcome market failures, further improve science-business integration, and reduce the regulatory burden.

Evidence suggests that for regions with lower levels of development, the business start-up process can be particularly difficult due to the underdevelopment of the overall innovation ecosystem and existing institutional failures [14]. Therefore, for such regions, along with SMARTspecialization policies, it is advisable to implement measures aimed at structural and technological change.

In addition, the development of an entrepreneurial ecosystem aimed at innovation is equally important for all regions. Traditionally, it consists of 5 elements [15]: 
- human capital. Measures to develop human capital should be aimed at: developing the workforce and strengthening the capacity of educational institutions in the region;

- financial resources - Increasing the volume and diversification of funding sources is a critical condition for the successful development of SMEs in the region;

- infrastructure and support - includes the following areas: direct physical infrastructure (roads, logistics and warehouses, Internet access and general telecommunications, etc.), organizational infrastructure: incubators, business associations, etc. and supporting professions, consultants, accountants, technical experts, lawyers, etc.);

- entrepreneurial culture - promotion of success stories, increasing the level of tolerance to risk and change, increasing the social status of the entrepreneur;

- market - improvement of distribution systems for new products, development of local business associations, cooperation with multinational and large domestic companies and more;

- management policies - regulatory policy, public financial and legislative support for innovation development.

In addition, it is important to encourage stakeholders in such areas to cooperate interregionally. The data show that SME companies from less developed regions are characterized by a relatively higher level of innovative development in the case of cooperation with companies in regions with a high concentration of knowledge and technology. Thus, joint projects, knowledge exchange can lead to the diffusion of innovations and accelerate the development of research areas. Cooperation between local SMEs and SMEs (or universities) from technologically developed regions leads to the flow of new technological and technical knowledge, managerial skills, general innovation culture, thereby compensating for the gaps in innovation ecosystems in regions with lower socio-economic development.

\section{Conclusions}

A model of clustering of regions based on key indicators of economic and innovative development of small and medium business using the method of $\mathrm{k}$ means is proposed. In the course of the research 8 indicators were tested, 5 of which were included in the final model: 1) innovative expenditures per capita; 2) GRP per capita; 3) Average salary; 4) export volumes per capita; 5) revenue for the SME sector. The use of these indicators allowed to comprehensively assess the level of development of small and medium-sized businesses in terms of regions of Ukraine.

The grouping of regions according to these features allowed to form 4 clusters and identify common characteristics of SME development. The first cluster includes 6 oblasts with the highest level of key development indicators. In this case, the areas in cluster 1 have a mixed industrial and 
agricultural orientation with a predominance of processing industry. The second cluster includes 3 oblasts that are leaders in all studied indicators, an important area of activity for them is the processing, mining and telecommunications industries. The third cluster is the most numerous: 10 oblasts with indicators close to the national average. Finally, the 4th cluster includes 5 oblasts with the lowest level of development.

The study allows asserting the heterogeneity of the main indicators of SME development among the regions of Ukraine and serves as a basis for further formation of recommendations for intensifying the innovative development of small and medium-sized businesses at the local level.

The conducted grouping of regions allowed to form recommendations on investment development of SMEs taking into account the level of development of each region. In particular, it was found that in developed regions it is advisable to focus on direct methods of financing, supporting some innovative initiatives. Whereas for less developed regions it is important to use indirect methods aimed at stimulating a wide range of enterprises. Indirect incentives should be aimed primarily at removing barriers to doing business and encouraging cooperation between major stakeholders in the region.

\section{References:}

1. Polishchuk Y., Ivashchenko A., Kornyliuk A. (2020) Regional Smart Specialization: Microbusiness impact. Baltic Journal of Economic Studies, no. 6(5), pp. 209-215. DOI: https://doi.org/10.30525/2256-0742/2020-6-5-209-215

2. OECD Regional Outlook 2019: Leveraging Megatrends fro Cities and Rural Areas. OECD Publishing, Paris. DOI: https://doi.org/10.1787/9789264312838-en

3. Mohnen P. R\&D tax incentives: issue and evidence. DEIP Maastricht. Available at: http://www.merit.unu.edu/DEIP/Presentations/Pierre\%20Mohnen\%20-\%20R\&D\%20TAX \%20INCENTIVES.pdf

4. Corporation tax and innovation. Issue at stake and review of European Union Experience in the Nineties Year. Available at: http://cordis.europa.eu/innovationpolicy/studies/fi_study1.htm

5. Hanel P. Impact Of Government Support Programs On Innovation By Canadian Manufacturing Firms. Available at: http://pages.usherbrooke.ca/gredi/wpapers/ 04_02_ph.pdf

6. Smart Guide to entrepreneurship support through clusters. European Commission July 2019. Available at: https://clustercollaboration.eu/sites/default/files/news_attachment/ eocic_smart_guide_to_entrepreneurship.pdf

7. Bator F. M. (2009) The Anatomy of Market Failure. The Quarterly Journal of Economics, no. 72, pp. 351-379.

8. Mainelli M. Financing Innovation: Viewing the UK from a global perspective. AEA \& Wolfson College. Available at: http://www.aeat.co.uk/cms/assets/Uploads/Papers-andReports/Wolfson-College/aeawolfsonApr10final.pdf

9. Randall L., Berlina A., Teräs J., Rinne T. Digitalisation as a Tool for Sustainable Nordic Regional Development: Preliminary Literature and Policy Review. Discussion Paper Prepared for Nordic Thematic Group for Innovative and Resilient Regions; Nordregio: Stockholm, Sweden, 2018. 
10. Cisco Global Digital Readiness Index 2019. White Paper. Available at: https://www.cisco.com/c/dam/en_us/about/csr/reports/global-digital-readiness-index.pdf

11. Cruysen van A., Hollanders H. (2008) Are specific policies needed to stimulate innovation in services? Workshop of DG Enterprise and Industry.

12. Gustafsson R., Autio E. Grounding for Innovation Policy: The Market, System and Social Cognitive Failure Rationales, Innovation Pressure - Rethinking Competitiveness, Policy and the Society. International ProACT conference. Available at: http://www.robingustafsson.net/publicationsp.php

13. Smith K. (1997) Economic infrastructures and innovation systems/ Systems of Innovation: Technologies, Institutions and Organizations. London: Pinter.

14. Mariachiara Barzotto, Carlo Corradini, Felicia Fai, Sandrine Labory \& Philip R. Tomlinson (2020) Smart specialisation, Industry 4.0 and lagging regions: some directions for policy, Regional Studies, Regional Science, 7:1, 318-332, DOI: 10.1080/ 21681376.2020.1803124

15. Isenberg D (2010) How to Start an Entrepreneurial Revolution, Harvard Business Review. Available at: https:// hbr.org/2010/06/the-big-idea-how-to-start-an-entrepreneurialrevolution/ar/1

16. De Noni, Ivan \& Orsi, Luigi \& Belussi, Fiorenza, 2018. «The role of collaborative networks in supporting the innovation performances of lagging-behind European regions,» Research Policy, Elsevier, vol. 47(1), pp. 1-13.

17. Mariachiara Barzotto, Carlo Corradini, Felicia M Fai, Sandrine Labory, Philip R. Tomlinson, Enhancing innovative capabilities in lagging regions: an extra-regional collaborative approach to RIS3, Cambridge Journal of Regions, Economy and Society, vol. 12, issue 2, July 2019, pp. 213-232. DOI: https://doi.org/10.1093/cjres/rsz003 